BIOTECHNOLOGY LETTERS

Volume 18 No. II (November 1996) pp.1277-1282

Received as revised 11 September

\title{
SELECTIVE MONOACETYLATION OF DIOL COMPOUNDS BY ASPERGILLUS NIGER LIPASE
}

\author{
Kwo-Feng Hsiao ${ }^{a}$, Fang-Lin Yang ${ }^{a}$, Shih-Hsiung Wu*a \\ and Kung-Tsung Wang $a, b$
}

a Institute of Biological Chemistry, Academia Sinica, 128, Yan-Chiu-Yuan Road, Sec II, Nankang, Taipei, Taiwan 115, R.O.C.

b Department of Chemistry, National Taiwan University, Taipei, Taiwan 107, R.O.C.

\begin{abstract}
Summary : The primary monoesters of diol compounds were formed exclusively in the reaction with vinyl acetate and Aspergillus niger lipase for $24 \sim 72 \mathrm{~h}$. Various diol compounds which included 1,3-butanediol, 1,4-butanediol, 1,5-hexanediol, 1-phenyl-1,2-ethanediol, 1-phenyl-1,3-propanediol, 2, 3, or 4-hydroxybenzyl alcohol, methyl 2, 3-O-acetyl-D-glycopyranosides and phenyl l-thio- $\beta$-D-xylopyranoside have been examined and showed nearly $100 \%$ regioselectivity.
\end{abstract}

\section{Introduction}

Selective acylation of one of two hydroxy groups in the diol compounds is an important step in organic synthesis (Kocienski, 1994). It is a challenge to develop a method for differentiating two hydroxy groups of diol compounds by direct monoacylation.

A number of chemical methods have been established for the selective acylation of primary hydroxy group of the diol compounds with specially activated acyl donors, amine bases or complex catalyst (Yamada, 1992; Ishihara et al. 1993). However, in these cases, a lower temperature or vigorous reaction conditions were required, and column chromatography had to be performed because of the mixtures resulted from the poor regioselectivities or diacetylated products formed in prolonged reaction time. In our approach, we developed an extremely simple, cheap, and highly regioselective method for obtaining primary monoacetates of diols.

Lipases have widespread applications in organic synthesis because of low cost, versatile nature, easy use and non-requirement of added cofactors (Chen \& Sih, 1989; Klibanov 1990; Wong \& Whiteside, 1994). Their regioselective capabilities have also been recognized in different hydroxy groups within the same molecule in the case of carbohydrate (Druekhammer et al. 1991), steroids and glycols (Cesti et al 1985; Janssen et al. 1991; Parmar et al. 1993). In our laboratory, lipase-catalyzed deacetylation in polyacetylated compounds have successfully differentiated primary and secondary position (Chang et al. 1991; Wu et al. 1992; Ong et al. 1993; Hsiao et al. 1993; Ong et al. 1994; Chen et al. 1995; Hsiao et al. 1995; Hsiao et al. 
1996). Based on the previous results, we extend the application of lipase-catalyzed acetyl transfer for the monoacetylation of primary hydroxyl group of diol compounds by using vinyl acetate as acetyl donor and solvent (Figure 1). Vinyl acetate is an inexpensive reagent and especially suitable for irreversible enzymatic acetyl transfer reaction (Wang \& Wong, 1988).<smiles>CC(O)CCO</smiles>

3a, b, c<smiles>OCCC(O)c1ccccc1</smiles>

$7 \mathrm{a}, \mathrm{b}, \mathrm{c}$

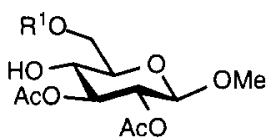

$11 \mathrm{a}, 11 \mathrm{~b}$<smiles>CC(O)CCCO</smiles>

$\mathbf{4 a}, \mathbf{b}, \mathbf{c}$<smiles>OCc1ccccc1O</smiles>

$\mathbf{8 a}, \mathbf{8 b}$

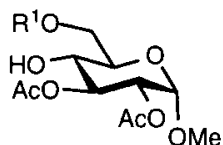

12a, 12b<smiles>CC(O)CCCCO</smiles>

$\mathbf{5 a}, \mathbf{b}, \mathbf{c}$<smiles>OCc1cccc(O)c1</smiles>

9a, 9b

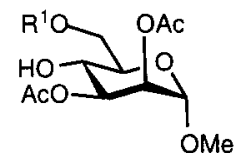

$13 a, 13 b$<smiles>OCC(O)c1ccccc1</smiles>

6a, b, c<smiles>Oc1ccc(CO[Ga])cc1</smiles>

$10 \mathrm{a}, 10 \mathrm{~b}$

Figure 1. The structures of diol compounds and monosaccharide derivatives.

$$
a R^{1}=R^{2}=H \quad b R^{1}=O A c, R^{2}=H \text { c } R^{1}=O A c, R^{2}=O A c
$$

Table 1. Characteristic chemical-shift region of ${ }^{1} \mathbf{H}$ NMR.

(a).

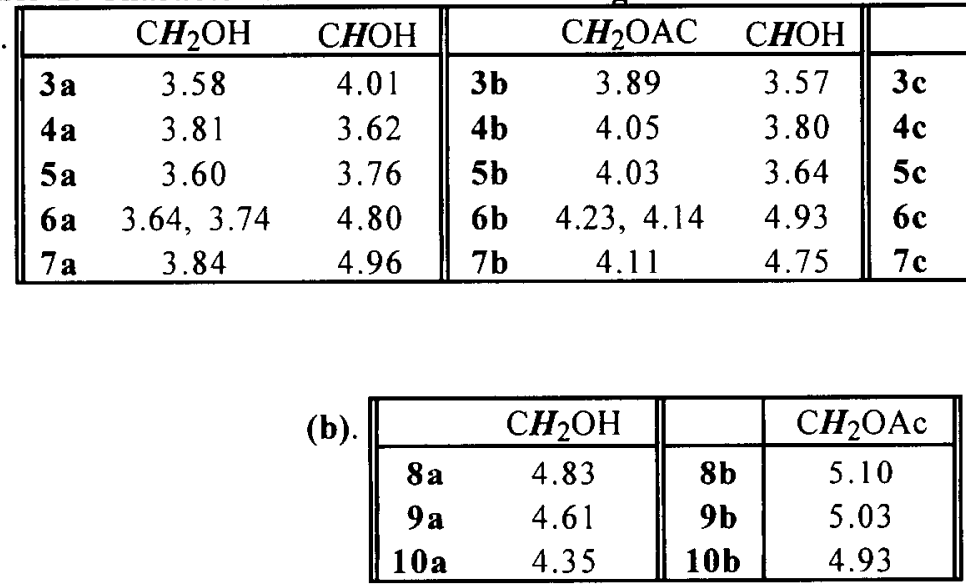




\section{Experimental}

General. : ${ }^{\mathrm{H}} \mathrm{NMR}$ spectra were recorded on a Bruker $\mathrm{AM}-400$ instrument in $\mathrm{CDCl}_{3}$ and were reported in $\delta$ units relative to $\mathrm{CHCl}_{3}$ fixed at $7.24 \mathrm{ppm}$. TLC was performed on precoated silica gel $\mathrm{G}$ plates (MERCK, $\mathrm{HF}_{254}$ ).

Aspergillus niger lipase was commercially available from Amano (Japan) and used without further purification. All the structures determination were performed by NMR and the position of acylation in all enzymatically prepared compounds were established by ${ }^{1} \mathrm{H}$ NMR which compared the corresponding diols and diacetates (Table 1). Vinyl acetate and diisopropylether were used without further purification apart from drying by shaking with $4 \AA$ molecular sieves.

\section{General Procedure for Lipase-Catalyzed Acetylation of Diols ( 3a, 4a and 5a ) with Vinyl Acetate in Diisopropylether.}

The diol substrate $(10 \mathrm{mmol}, 0.9 \mathrm{~g}$ for $3 \mathrm{a}, 1.04 \mathrm{~g}$ for $4 \mathrm{a}, 1.18 \mathrm{~g}$ for $5 \mathrm{a})$ and vinyl acatate $(25 \mathrm{ml})$ were dissolved in diisopropylether $(25 \mathrm{ml})$. After $2 \mathrm{~g}$ Aspergillus niger lipase was added, the mixture was shaken at room temperature, and the reaction was monitored by GLC and NMR for the conversion by withdrawing $2 \mathrm{~mL}$ reaction solution in each interval, $1.8 \mathrm{ml}$ for NMR and $0.2 \mathrm{~mL}$ for GLC respectively. Once the required extent of conversion was reached, the enzyme was filtered off and the solvent was removed by evaporation in a stream of nitrogen. All the structures were determined in a crude mixture and compared with authentic compounds. GLC for the seperation of the relating derivatives with a Chromosorb 5-ft WHP column with $5 \% \mathrm{OV}-101$ as the stationary phase. Carrier gas $\mathrm{N}_{2}, 30 \mathrm{~mL} \cdot \mathrm{min}^{-1}$, injector temperature $60^{\circ} \mathrm{C}$, $100^{\circ} \mathrm{C}, 3{ }^{\circ} \mathrm{C} \cdot \mathrm{min}^{-1}, 200^{\circ} \mathrm{C}$. Retention time (min); 3a (13.86), 3b (10.81), 3c (8.74), 4a (16.37), 4b (14.56), 4c (12.25), 5a (19.73), 5b (17.56), 5c (15.56). Selected characteristic ${ }^{1} \mathrm{H} N M R: 1-O$-acetyl-1,4pentanediol $(\mathbf{4 b}) ; \delta_{\mathrm{H}}\left(400 \mathrm{MHz}_{\mathrm{CDCl}}\right) 1.09(\mathrm{~d}, 3 \mathrm{H}), 1.32 \sim 1.71(\mathrm{~m}, 4 \mathrm{H}), 1.94\left(\mathrm{~s}, 3 \mathrm{H}, \mathrm{COCH}_{3}\right), 2.59(\mathrm{~s}$, $1 \mathrm{H}, \mathrm{OH}), 3.80(\mathrm{~m}, 1 \mathrm{H}), 4.05(\mathrm{t}, 2 \mathrm{H}) .1,4-O$-diacetyl-1,4-pentanediol $(4 \mathrm{c}) ; \delta_{\mathrm{H}}(400 \mathrm{MHz}, \mathrm{CDCl} / 3) 1.12(\mathrm{~d}$, $3 \mathrm{H},), 1.34 \sim \mathrm{I} .72(\mathrm{~m}, 4 \mathrm{H}), 1.94,1.95\left(2 \mathrm{~s}, 6 \mathrm{H}, \mathrm{COCH}_{3}\right), 4.03(\mathrm{t}, 2 \mathrm{H}), 4.90(\mathrm{~m}, 1 \mathrm{H}) .1-\mathrm{O}$-acetyl-1,5hexanediol $(\mathbf{5 b}) ; \delta_{\mathrm{H}}\left(400 \mathrm{MHz}_{\mathrm{CDCl}}\right) 1.03(\mathrm{~d}, 3 \mathrm{H}), 1.23 \sim 1.59(\mathrm{~m}, 6 \mathrm{H}), 1.90\left(\mathrm{~s}, 3 \mathrm{H}, \mathrm{COCH}_{3}\right), 2.77(\mathrm{~s}$, $1 \mathrm{H}, \mathrm{OH}), 3.64(\mathrm{~m}, 1 \mathrm{H}), 4.03(\mathrm{t}, 2 \mathrm{H}) .1,5-O$-diacetyl-1,5-hexanediol $(5 \mathrm{c}) ; \delta_{\mathrm{H}}\left(400 \mathrm{MHz}, \mathrm{CDCl}_{3}\right) 1.07(\mathrm{~d}$, $3 \mathrm{H}), 1.32 \sim 1.70(\mathrm{~m}, 6 \mathrm{H}), 1.91,1.94\left(2 \mathrm{~s}, 6 \mathrm{H}, \mathrm{COCH}_{3}\right), 4.01(\mathrm{t}, 2 \mathrm{H}), 4.86(\mathrm{~m}, 1 \mathrm{H})$.

\section{General Procedure for Lipase-Catalyzed Acetylation of Diols ( 6 a and 7a ) with Vinyl Acetate in Diisopropylether.}

The diol substrate $(10 \mathrm{mmol}, 1.38 \mathrm{~g}$ for $6 \mathrm{a}, 1.52 \mathrm{~g}$ for $7 \mathrm{a})$ and vinyl acatate $(25 \mathrm{~mL})$ are dissolved in diisopropylether $(25 \mathrm{~mL})$. After $2 \mathrm{~g}$ Aspergillus niger lipase was added, the mixture was stirred at room temperature, and the reaction was monitored by NMR for the conversion by withdrawing $2 \mathrm{~mL}$ reaction solution in each interval for ${ }^{1} \mathrm{H}$ NMR. Once the required extent of conversion was reached, the enzyme was filtered off and the solvent was removed by evaporation in a reduced pressure at $30^{\circ} \mathrm{C}$.

\section{General Procedure for Lipase-Catalyzed Acetylation of Diols ( 8a, 9a and 10a) with Vinyl Acetate in Diisopropylether.}

The diol substrate $(10 \mathrm{mmol}, 1.24 \mathrm{~g})$ and vinyl acatate $(25 \mathrm{~mL})$ are dissolved in diisopropylether $(25 \mathrm{~mL})$. After $2 \mathrm{~g}$ Aspergillus niger lipase was added, the mixture was shaken at $240 \mathrm{rpm}$ at room temperature, and the reaction was monitored by ${ }^{\prime} \mathrm{H}$ NMR for the conversion by withdrawing $2 \mathrm{ml}$ reaction solution in each interval for NMR analysis. Once the required extent of conversion was reached, the enzyme was filtered off and the solvent was removed by evaporation in a reduced pressure at $30^{\circ} \mathrm{C}$.

\section{General Procedure for Lipase-Catalyzed Acetylation of Diols ( 11a, 12a and 13a ) with Vinyl Acetate in Diisopropylether.}

The diol substrate $(0.5 \mathrm{mmol}, 140 \mathrm{mg})$ and vinyl acatate $(5 \mathrm{~mL})$ was dissolved in diisopropylether $(5 \mathrm{~mL})$. After $0.5 \mathrm{~g}$ Aspergillus niger lipase was added, the mixture was shaken at $240 \mathrm{rpm}$ at room temperature, and the reaction was monitored by HPLC for the conversion by withdrawing $0.2 \mathrm{~mL}$ reaction solution in each interval. Once the required extent of conversion was reached, the enzyme was filtered off and the solvent was removed by evaporation. The peaks assignment and area were studied with the established compounds (Hsiao et al. 1993). HPLC analyses were performed on a Hitachi L-6200A intelegent pump

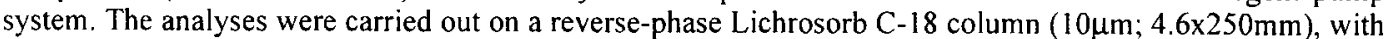
the solvent mixture of $20 \% \mathrm{CH}_{3} \mathrm{CN}(\mathrm{aq})$; the flow rate was $1 \mathrm{~mL} \cdot \mathrm{min}^{-1}$, and dectection was performed at 214 $\mathrm{nm}$. Retention time $(\mathrm{min}): 11 \mathrm{a}(5.8), 11 \mathrm{~b}(12.3), 12 \mathrm{a}(5.4), 12 \mathrm{~b}(11.4), 13 \mathrm{a}(5.7), 13 \mathrm{~b}$ (12.0). Selected characteristic ${ }^{1} \mathrm{H}$ NMR : methyl 2,3,4-O-triacetyl- $\beta$-D-glucopyranoside $(11 \mathrm{~b}) ; \delta_{\mathrm{H}}\left(400 \mathrm{MHz}, \mathrm{CDCl}_{3}\right) 1.97$, 
$1.99,2.01\left(3 \mathrm{~s}, 3 \mathrm{H}, \mathrm{COCH}_{3}\right) 3.40(\mathrm{~s}, 3 \mathrm{H}, \mathrm{OMe}), 3.48\left(\mathrm{ddd}, 1 \mathrm{H}, \mathrm{H}-5, J_{5,6}=1.7 \mathrm{~Hz}, J_{5,6}=3.9 \mathrm{~Hz}\right), 3.54$ $\left(\mathrm{t}, 1 \mathrm{H}, \mathrm{H}-4, J_{4,5}=9.1 \mathrm{~Hz}\right), 4.28\left(\mathrm{dd}, 1 \mathrm{H}, \mathrm{H}-6, J_{6,6^{\prime}}=12.2 \mathrm{~Hz}\right), 4.36\left(\mathrm{~d}, 1 \mathrm{H}, \mathrm{H}-1, J_{1,2}=9.5 \mathrm{~Hz}\right), 4.39$ (dd, $1 \mathrm{H}, \mathrm{H}-6$ '), $5.25\left(\mathrm{t}, 1 \mathrm{H}, \mathrm{H}-3, J_{3,4}=8.6 \mathrm{~Hz}\right.$ ). methyl 2,3,4-O-triacetyl- $\alpha-\mathrm{D}$-glucopyranoside $(12 \mathrm{~b}) ; \delta_{\mathrm{H}}$ $\left(400 \mathrm{MHz}_{2} \mathrm{CDCl}_{3}\right) 2.06,2.07,2.13\left(3 \mathrm{~s}, 3 \mathrm{H}, \mathrm{COCH}_{3}\right), 3.29(\mathrm{br}, 1 \mathrm{H}, \mathrm{OH}), 3.48$ (s, 3H, OMe), 3.52 (bt, $\left.1 \mathrm{H}, \mathrm{H}-4, J_{4,5}=9.6 \mathrm{~Hz}\right), 3.78\left(\mathrm{ddd}, 1 \mathrm{H}, \mathrm{H}-5, J_{5,6}=2.3, J_{5,6^{\prime}}=4.7 \mathrm{~Hz}\right), 4.10(\mathrm{br}, 1 \mathrm{H}, \mathrm{H}-4), 4.26(\mathrm{dd}, 1 \mathrm{H}$, $\left.\mathrm{H}-6, J_{6,6^{\prime}}=12.1 \mathrm{~Hz}\right), 4.37\left(\mathrm{dd}, 1 \mathrm{H}, \mathrm{H}-6^{\prime}\right), 4.79\left(\mathrm{dd}, 1 \mathrm{H}, \mathrm{H}-2, J_{2,3}=10.0 \mathrm{~Hz}\right), 4.84\left(\mathrm{~d}, 1 \mathrm{H}, \mathrm{H}-1, J_{1.2}=3.7\right.$ $\mathrm{Hz}), 5.25\left(\mathrm{t}, 1 \mathrm{H}, \mathrm{H}-3, J_{3,4}=9.4 \mathrm{~Hz}\right)$. methyl 2,3,4-O-triacetyl- $\alpha$-D-mannopyrannoside $(13 \mathrm{~b}) ; \delta_{\mathrm{H}}(400$ $\left.\mathrm{MHz}, \mathrm{CDCl}_{3}\right) 2.11,2.17,2.18\left(3 \mathrm{~s}, 3 \mathrm{H}, \mathrm{COCH}_{3}\right), 2.87(\mathrm{br}, 1 \mathrm{H}, \mathrm{OH}), 3.47$ (s, 3H, OMe), 3.77 (br, 2H, H-4, $\mathrm{H}-5)$, ), $4.28\left(\mathrm{dd}, 1 \mathrm{H}, \mathrm{H}-6, J_{5,6}=1.4 \mathrm{~Hz}, J_{6,6^{\prime}}=12.1 \mathrm{~Hz}\right), 4.48\left(\mathrm{dd}, 1 \mathrm{H}, J_{5,6^{\prime}}=4.6 \mathrm{~Hz}, \mathrm{H}-6^{\prime}\right), 4.64(\mathrm{~d}$, $\left.1 \mathrm{H}, \mathrm{H}-1, J_{1,2}=1.5 \mathrm{~Hz}\right), 5.15(\mathrm{~m}, 2 \mathrm{H}, \mathrm{H}-2, \mathrm{H}-3)$.

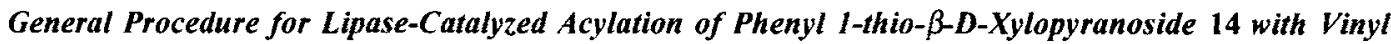 Acetate.}

The substrate $14(20 \mathrm{mg})$ and Aspergillus niger lipase (200 mg) were mixed in $5 \mathrm{~mL}$ vinyl acetate. The followings are described as above mentioned. There was no reaction occurred for reaction $24 \mathrm{~h}$.

\section{Results and Discussion}

Simple aliphatic alcohols, such as 1-hexanol (1a), 2-hexanol (2a) and 1,5-hexanediol (5a), were used initially as the model substrates for lipase screening. As shown in Scheme 1, compound 1a could be converted into the corresponding acetate by Aspergillus niger lipasecatalyzed transesterification in vinyl acetate solution; while no corresponding acetate was formed in the case of compound $\mathbf{2 a}$ in the same reaction condition for $36 \mathrm{~h}$. As for 1,5hexanediol (5a), only corresponding primary ester was formed after reaction for $36 \mathrm{~h}$. The results strongly indicated that primary and secondary hydroxyl groups in diol compounds might be differentiated by Aspergillus niger lipase-catalyzed acetylation in vinyl acetate solution and corresponding primary monoacetates could be obtained. Therefore, in order to establish a general regioselectively monoacetylated method, several different diol compounds have been tested by the reaction of Aspergillus niger lipase-catalyzed transesterification.

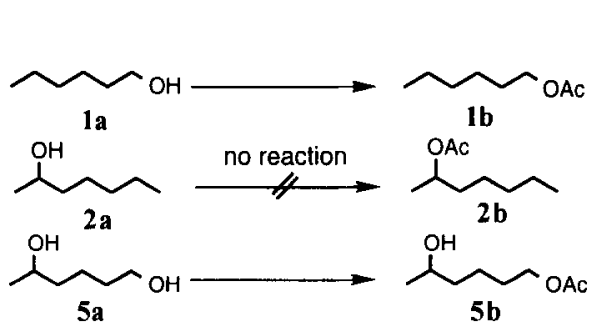

Scheme 1. Aspergillus niger lipase-catalyzed selective acetylation of primary alcohol.

Reaction conditions : a mixture of an alcohol (5 $\mathrm{mmol}, 511 \mathrm{mg}$ for $\mathbf{1 a}$ and $\mathbf{2 a}, 590 \mathrm{mg}$ for $\mathbf{5 a}$ ) and Aspergillus niger lipase $(1 \mathrm{~g})$ in vinyl acetate $(20 \mathrm{~mL})$ was shaken at $240 \mathrm{rpm}$ at room temperature. Aliquotes was withdrawn from the reaction mixture for the analysis by GLC at different time intervals. The analysis was the same as the description in the experimental section.

As expected, it was observed that primary monoesters were formed quantitatively relative to the conversion of diol compounds by Aspergillus niger lipase-catalyzed transesterification. The results are listed in Table 2. The common feature in these reactions is 
that the substrates were acetylated exclusively on primary hydroxyl position and no other side products were observed. The structure of the products are easily identified by comparing the signals of $\mathrm{CH}_{2} \mathrm{OH}$ and $\mathrm{CH}_{2} \mathrm{OAc}$ of substrates and products in ' $\mathrm{H}$ NMR spectra. In the series of aliphatic diols (3a, $4 \mathbf{a}$ and $5 \mathbf{a}$ ), they are different in the chain length between primary and secondary hydroxy groups. Free diols could be converted into primary monoacetates in $12 \mathrm{~h}$ reaction and no diacetate or secondary monoacetate could be detected in our study by GLC analysis. When the reaction time was prolonged until $48 \mathrm{~h}$, only trace amounts of diacetate appeared in the chromatogram of GLC analysis. It implied that the moiety of secondary alcohols difficultly entered the active site of Aspergillus niger lipase.

The same reaction system was also examined with 1-phenyl-1,2-ethanediol (6a) and 1phenyl-1,3-propanediol (7a). The corresponding primary monoacetates were obtained as well.

Table 2. Aspergillus niger lipase-catalyzed selective acetylation of diol compounds on primary position with vinyl acetate in organic solvent.

\begin{tabular}{|c|c|c|c|c|}
\hline \multirow[b]{2}{*}{ Substrate } & \multirow{2}{*}{$\begin{array}{l}\text { Time } \\
\text { (hour) }\end{array}$} & \multicolumn{3}{|c|}{ Compounds Distribution (\%) } \\
\hline & & $\overline{\text { Diol }}$ & Monoester $^{\mathrm{a}}$ & $\overline{\text { Diester }}$ \\
\hline $3 \mathbf{a}$ & 24 & 0 & 98 & 2 \\
\hline $4 \mathbf{a}$ & 24 & 0 & 98 & 2 \\
\hline $5 \mathbf{a}$ & 24 & 0 & 98 & 2 \\
\hline $6 \mathbf{a}$ & 72 & 0 & 100 & 0 \\
\hline $7 \mathbf{a}$ & 72 & 5 & 95 & 0 \\
\hline $\mathbf{8 a}$ & 48 & 7 & 93 & 0 \\
\hline 9a & 48 & 11 & 89 & 0 \\
\hline $10 \mathrm{a}$ & 48 & 23 & 77 & 0 \\
\hline $11 \mathrm{a}$ & 48 & 37 & 63 & 0 \\
\hline $12 \mathrm{a}$ & 48 & 24 & 76 & 0 \\
\hline $13 \mathbf{a}$ & 48 & 29 & 71 & 0 \\
\hline 14 & 24 & - & - & - \\
\hline
\end{tabular}

a Only primary monoester formed.

It is interesting that 2,3, or 4-hydroxybenzyl alcohol $(\mathbf{8 a}, 9 \mathbf{a}, \mathbf{1 0 a})$ which reacted with Aspergillus niger lipase in vinyl acetate was transformed into the benzyl acetate derivatives, respectively. The higher reaction rate was observed in the substrate whose primary hydroxy group was closer to the phenyl ring. It may imply that the phenyl ring in the substrate hydrobically interacts with Aspergillus niger lipase molecule adjcent to the active site and somehow enhance the enzymatic reaction. 
In order to evaluate the application of Aspergillus niger lipase-catalyzed transesterification to carbohydrate molecules, three partially protected monosaccharides (11a, 12a and 13a) were also tested. Only the primary hydroxy group $(6-\mathrm{OH})$ could attack the acetyl enzyme intermediates to form acetate. Although their reaction rate was much slower than aliphatic diol compounds, the catalytic efficiency and regiospecificity was enough to get the derivatives of monosaccharides at preparative scale. Phenyl 1-thio- $\beta$-D-xylopyranoside (14) with three secondary hydroxyl groups was also examined as a substrate. There was no acetate products formed in $24 \mathrm{~h}$. It gave more proof that Aspergillus niger lipase hardly accepted secondary hydroxyl group as a substrate in acetyl transfer reaction.

Only the primary monoester is produced quantitatively relative to the conversion of the starting diol. In conclusion, it is believed that Aspergillus niger lipase-catalyzed acetyl transfer can be used as an efficient, simple and mild method to selectively catalyze the formation of primary acetate derivatives from diol compounds in excellent yields.

\section{References :}

Cesti, P.; Zaks, A.; Klibanov, A. M. (1985). Appl. Biochem. Biotechnol. 11, 401.

Chang, K. Y.; Wu, S. H.; Wang, K. T. (1991). Carbohydr. Res. 222, 121.

Chang, K. Y.; Wu, S. H.; Wang, K. T. (1991). J. Carbohydr. Chem. 10, 251.

Chen, C. S.; Sih, C. J. (1989). Angew. Chem. Int. Eng. Ed. 28, 695.

Chen, H. P.; Hsiao, K. F.; Wu, S. H.; Wang, K. T. (1995). Biotechnol. Lett. 17, 305.

Drueckhammer, D. G.; Hennen, W. J.; Pederson, R. L.; Barbas, III, C. F.; Gautheron, C. M.; Krach, T.; Wong, C. H. (1991). Synthesis, 499.

Hsiao, K. F.; Wu, S. H.; Wang, K. T. (1993). Bioorg. Med.. Chem. Lett. 3, 2125.

Hsiao, K. F.; Yang, F. L.; Wu, S. H.; Wang, K. T. (1995). Biotechnol. Lett. 17, 963.

Hsiao, K. F.; Chen, S. T.; Wu, S. H.; Wang, K. T., (1996). SynLett. (in press).

Ishihara, K.; Kurihara, H.; Yamamoto, H. (1993). J. Org. Chem. 58, 3791. and references cited therein.

Janssen, A. J. M; Klunder, A. J. H; Zwanenburg, B. (1991). Tetrahedron. 47, 7409.

Klibanov, A. M. (1990). Acc. Chem. Res. 23, 114.

Kocienski, P. J. (1994). Protecting Groups; Thieme; New York.

Ong, G. T.; Chang, K. Y.; Wu, S. H.; Wang, K. T. (1993). Carbohydr. Res. 241, 327.

Ong, G. T.; Chang, K. Y.; Wu, S. H.; Wang, K. T. (1994). Carbohydr. Res. 265, 311.

Parmar, V. S.; Sinha, R.; Bisht, K. S.; Gupta, S.; Prasad, A. D.; Taneja, P. (1993). Tetrahedron, $49,4107$.

Wang, Y. F.; Wong, C. H. (1988). J. Org. Chem. 53, 3127.

Wong, C. H.; Whiteside G. M. (1994). Enzymes in Synthetic Organic Chemistry, 1st ed.; Elsevier; New York.

Wu, S. H.; Ong, G. T.; Hsiao, K. Y.; Wang, K. T. (1992). J. Chin. Chem. Soc. 39, 675.

Yamada, S. (1992). J. Org. Chem. 57, 1591. 